\title{
HEALTH CONSCIOUS CONSUMER BEHAVIOUR: THE IMPACT OF A PANDEMIC ON THE CASE OF SLOVAKIA
}

\section{Čvirik, M.}

Marián Čvirik / University of Economics in Bratislava, Faculty of Commerce, Department of Marketing, Dolnozemská cesta 1, 85235 Bratislava, Slovakia.Email: marian.cvirik@euba.sk.

\begin{abstract}
The adverse effects of the pandemic (COVID-19) are already reflected in the Slovak economy. At the same time, some experts warn that the pandemic is not over and may manifest itself in the second wave. The article examines the concept of Health consciousness as one of the possible (preventive) measures in a pandemic. The aim is fourfold: 1 . to measure the level of health consciousness in normal conditions 2 . to measure the level of health consciousness during a pandemic 3. to examine the differences between these levels and 4 . to determine the true meaning of health consciousness in a pandemic. A sample of 384 respondents was employed in the research to collect the empirical data. The sample was selected by the quota method. The study consisted of two phases - the first phase before the pandemic and the second phase during the pandemic (COVID-19). The one-way ANOVA test and linear regression analysis were used to explore the impact of selected factors on health consciousness in the Slovak population and to verify the hypotheses. The results of the research indicate that health consciousness increased sharply during the pandemic. At the same time, selected demographic factors were confirmed as factors influencing the level of health consciousness. The level of health consciousness can affect the frequency of infections. The results can be used in many fields (medicine, sociology, psychology, marketing), both theories and practice.

Implications for a Central European audience: The development of the Slovak economy at the end of 2019 led to a more positive estimate of GDP growth and other economic indicators. The situation has changed in the context of the pandemic. Especially small and medium-sized enterprises represent a vulnerable place in the Slovak economy. We must look for possible ways to eliminate the pandemic and at the same time look for effective preventive means that could be used in the event of a second wave or another pandemic to protect human lives as well as the state economy.
\end{abstract}

Keywords: health consciousness; consumer health behaviour; COVID-19 JEL Classification: M30, I11, I19

\section{Introduction}

The issue of the health consciousness of the people of the state is highly crucial in all circumstances. However, the emphasis on health consciousness is increased during the pandemic that has occurred in Slovakia. A pandemic can be understood as a global outbreak of the disease. Several cases of pandemics (Spanish flu, Asian flu, Hong Kong flu, swine flu pandemic) can be found in the distant past, but most recently it is the COVID-19 
pandemic declared by the World Health Organization on March 12, 2020. SARS-CoV-2 is a new virus responsible for an outbreak of respiratory illness known as novel coronavirus disease 2019 (COVID-19). SARS (severe acute respiratory syndrome) induced by the new coronavirus (COVID-19) affected the lives of not only the Slovaks but also the world.

The mentioned pandemics (Spanish influenza, Asian influenza, Hong Kong influenza) had a limited economic impact due to lower globalization. Therefore, today's coronavirus is much more dangerous for the economic sector. In times of previous pandemics, we could talk about lower international trade, while today it is a global market. All countries of the European Union (as well as the whole world) are connected by customer and supply channels. The states of the European Union forming the Schengen are practically linked into one area by monetary politicians, which poses a significant risk of weakening the euro.

The impact of the pandemic is gradually being transmitted to all areas of the Slovak economy. We can look at the market from three entities operating in the market: households, companies and the state. In the first place, the virus will affect the functioning of businesses that have had to suspend their business to limit the spread of coronavirus among consumers. Due to the loss of income, companies will incur losses. The most endangered companies are engaged in the provision of services (accommodation and catering services) and recreation. The insolvency of companies will cause redundancies, which will be reflected in an increase in the unemployment rate. Quarantine measures are aimed at limiting the effects of a pandemic on human lives. However, this slows down the production of products and stops the provision of services, which will be reflected in declining incomes, minimizing added value and rising unemployment. The state has already started its role as a healer of the economic situation with various measures, but there are fears that this assistance will not be sufficient (Baláž, 2020; Dun \& Bradstreet, 2020; Nozdrovická, 2020).

It can be stated that the best weapon against the effects of a pandemic is its reduction and elimination from the very beginning.

During the pandemic, however, the media and various societies have overwhelmed information about prevention, health and the successful management of this difficult situation. But how is this situation affected by the health consciousness of the population? Which segments have increased health consciousness? Based on the information presented daily in the media, it can be concluded that there are differences in the number of infected concerning regions. If we understand health consciousness as a prevention factor, is there a relationship between health consciousness and the number of people infected with the regions? These and other questions can be answered in our primary research article.

\section{Theoretical background}

The most used and most accepted definition of health is that of the World Health Organization (abbrev WHO). WHO (2020) defined health as "a state of complete physical, mental and social well-being and not merely the absence of disease or infirmity". Stokes, Noren, \& Shindell (1982) defined heal as a state characterized by anatomic, physiologic and psychological integrity; ability to perform personally valued family, work and community roles, ability to deal with physical, biological, psychological and social stress". 
Health consciousness refers to the extent to which an individual tends to undertake health actions (Gould,1988). Gould defines health consciousness as the inner status of a person regarding health (Gould, 1990). As many studies say (e. g. Kemp \& Bui, 2011), a globally growing segment of consumers who are aware of health. Some newer definitions even go beyond this scope and consider the importance of health consciousness in a broader context such as in disease prevention (Sørensen et al., 2012).

Health consciousness is defined as the motivation that stimulates consumers to take health activities and prevent it (Jayanti \& Burns, 1998; Michaelidou \& Hassan, 2008). They strive to improve and / or maintain their welfare by engaging in healthy behaviours, such as eating healthy food, physical activity, caring for prevention, and the like.

Previous research has revealed health awareness supports preventive health care (Jayanti \& Burns, 1998) and consumer shopping behaviour (Lockie et al., 2002).

Consumers in Indonesia are moving toward a healthy lifestyle focused on health and hygiene, according to a recent SurveySensum survey in collaboration with the Mobile Marketing Association, as the country continues its efforts to stop the spread of COVID-19. Based on the above survey, it can be stated that in Indonesia, in connection with COVID19, water consumption increased (approximately $55 \%$ ), increased handwashing intensity (about $85 \%$ ) and also the area of prevention (vitamin consumption increased by $46 \%$ and fruit consumption and vegetables increased by $47 \%$ ) (Warc, 2020). It can be stated that the pandemic has created pressure to increase health care and prevention while increasing health awareness.

At the end of December 2019, Chinese public health authorities reported several cases of acute respiratory syndrome in Wuhan, Hubei Province, China. Chinese scientists soon identified the new coronavirus as the leading agent. The disease is now referred to as Coronavirus Disease 2019 (COVID-19), and the causative virus is called Severe Coronavirus 2 Acute Respiratory Syndrome (SARS-CoV-2). It is a new coronavirus strain that has not been previously identified in humans.

As stated by the European Centre for Disease Prevention and Control: "The COVID-19 pandemic is rapidly evolving, and outbreak investigations are ongoing. ECDC is closely monitoring this outbreak, providing risk assessments, public health guidance, and advice on response activities to the EU Member States and the EU Commission." (ECDPC, 2020).

Slovakia is up to date April 09. 2020 confirmed cases of infection (PHASR, 2020). It is recommended to cover the nose and mouth when coughing or sneezing (Center for Disease Control and Prevention 2020a). As reported by Gostic et al. (2020), foreign travellers showing any symptoms of SARS-CoV-2 should be isolated and quarantined to prevent further transmission (Gostic et al., 2020).

As there is still no effective legal remedy, several experts state that the most important is proper prevention and health consciousness of individuals (e.g., Center for Disease Control and Prevention, 2020a, b; Chen et al., 2020; Gostic et al., 2020). 


\section{Methodology}

The aim is fourfold: 1 . to measure the level of health consciousness in normal conditions 2 . to measure the level of health consciousness during a pandemic 3 . to examine the differences between these levels and 4. to determine the true meaning of health consciousness in a pandemic.

A pandemic threatens each demographic group differently. Seniors over 65 are considered the most vulnerable group (Adler, 2020). Less than $1 \%$ of the cases were reported in kids younger than ten years of age (Wu \& McGoogan, 2020) This is one of the reasons why we have also looked at demographic factors - age, gender and region. We have, therefore chosen a quota sample to maintain these demographic variables from the basic population.

The first stage was to determine quotas in the basic population (see Table 1). Quotas for research were age, gender and residence (region). The second stage was to apply quotas to create the sample what can be seen in Table 1. The basis for our research was 384 respondents.

Table 1 I Quotas and their application (Quotas sample)

\begin{tabular}{c|l|c|c}
\hline \multicolumn{2}{c|}{ Factors } & Quotas [\%] & Quotas applied [pcs.] \\
\hline \multirow{2}{*}{ Gender } & Men & 48.8 & 187 \\
& Women & 51.2 & 197 \\
\hline \multirow{3}{*}{ age } & $15-39$ years old & 40.3 & 155 \\
& 40-64 years old & 41.3 & 159 \\
& Older than 65 years & 18.4 & 70 \\
\hline \multirow{5}{*}{ Region } & Banskobystrický & 12.03 & 46 \\
& Bratislavský & 11.67 & 45 \\
& Košický & 14.68 & 56 \\
& Nitrianský & 12.58 & 48 \\
& Prešovský & 15.12 & 58 \\
& Trenčianský & 10.87 & 42 \\
& Trnavský & 10.31 & 40 \\
& Žilinský & 12.72 & 49 \\
\hline \multirow{2}{*}{$\Sigma$} & & $\mathbf{1 0 0}$ & $\mathbf{3 8 4}$
\end{tabular}

Source: author based on SOSR (2020)

As shown in Table 1, the sample surveyed represents a representative sample of the population of Slovakia older than 15 years according to the following quotas: age, gender and residence (region). For the sample of 384 respondents, the maximum statistical error (with a $95 \%$ confidence probability) is around $6 \%$.

Consumer health consciousness was measured based on Health Consciousness Scale (HCS). The original HCS is composed of nine items scored on 5-point scales ranging from 0 to 4. However, four factors relating to HCS were empirically identified (overall alertness, self-consciousness, involvement self-monitoring of one's health). Item scores can be summed to form an overall HCS score ranging from 0 (minimum) to 36 (maximum). The total HCS score can be split at the median to form two groups: high health consciousness and low health consciousness (Gould, 1988).

The research was carried out in two phases. 
The first phase took place between 14.09.2019 to 01.11.2019. This phase aimed to measure consumer health consciousness.

Mean scores, standard deviations and Cronbach's alphas for the items of HCS_1 (for phase one) are presented in Table 2.

Table 2 I HCS 1

\begin{tabular}{l|c|c|c}
\hline \multicolumn{1}{c|}{ HEALTH CONSCIOUSNESS SCALE: HCS* } & $\begin{array}{c}\text { Mean } \\
\text { scores }\end{array}$ & St. dev. & $\begin{array}{c}\text { Cronbach's } \\
\text { alpha }^{\star *}\end{array}$ \\
\hline 1. I reflect about my health a lot. & 1.532 & 0.781 & 0.739 \\
2. I'm very self-conscious about my health. & 0.739 & 0.440 & 0.758 \\
3. I'm generally attentive to my inner feelings about my health. & 0.926 & 0.262 & 0.759 \\
4. I'm constantly examining my health. & 0.901 & 0.299 & 0.744 \\
5. I'm alert to changes in my health. & 1.317 & 0.765 & 0.712 \\
6. I'm usually aware of my health. & 1.137 & 0.666 & 0.724 \\
7. I'm aware of the state of my health as I go through the day. & 1.458 & 0.753 & 0.723 \\
8. I notice how I feel physically as I go through the day. & 1.553 & 0.630 & 0.705 \\
9. I'm very involved with my health. & 1.373 & 0.714 & 0.756 \\
\hline
\end{tabular}

Notes: * Based on Gould (1988).

**Overall Alpha $=0.759$.

Source: author

Cronbach's alpha is used to investigate the reliability (accuracy and reliability of a research tool) within the internal consistency of the selected scale. As we can see, the total value of Cronbach's alpha value is 0.759 , which can be interpreted as high value (Tavakol \& Dennick, 2011). From a practical point of view, it should also be stated that if the Cronbach's alpha value for the individual statements is higher than a total value, it is advisable to exclude this statement in future researches, as this will increase the overall accuracy and reliability of the research tool - in our case HCS_1. As we can see, it is not appropriate to rule out any of the statements, even though excluding statement 3 would not alter the overall reliability. The standard deviation of the mean represents the dispersion of the calculated arithmetic mean across the different samples selected from one main population. The standard deviation shows to what extent the individual measured values are around the mean value. The smaller the standard deviation, the closer the measured values are around the mean value. If the variance is smaller, it can be understood that the statement was rated similarly by all respondents. In our case, we can see slight standard deviation (in all cases the value was less than 0.785 ). In some cases (e.g. issue 2), the respondents' answers were almost identical.

The second phase took place between 01.03.2020 to 10.04.2020, when the COVID-19 pandemic broke out in Slovakia. The aim of this phase was to re-measure consumers' health consciousness and to examine changes in consumer behaviour. It should be noted that the author's primary intention was not to explore this change, but the situation requires closer examination in this period.

The sample of the first phase and the second is almost identical. In the second phase, respondents were contacted by e-mail (or telephone) based on the contacts they provided 
on the questionnaire. The return rate was $83.6 \%(n=321)$, which means that in the second phase, $16.4 \%(n=63)$ of new respondents were selected based on quotas.

Mean scores, standard deviations and Cronbach's alphas for the items of HCS_2 (for phase two) are presented in Table 3.

Table 3 I HCS_2

\begin{tabular}{l|c|c|c}
\multicolumn{1}{c|}{ HEALTH CONSCIOUSNESS SCALE: HCS } & $\begin{array}{c}\text { Mean } \\
\text { scores }\end{array}$ & St. dev. & $\begin{array}{c}\text { Cronbach'S } \\
\text { alpha** }^{*}\end{array}$ \\
\hline 1. I reflect about my health a lot. & 3.755 & 0.594 & 0.828 \\
2. I'm very self-conscious about my health. & 2.445 & 1.455 & 0.847 \\
3. I'm generally attentive to my inner feelings about my & 2.997 & 1.217 & 0.818 \\
health. & 3.292 & 1.208 & 0.824 \\
4. I'm constantly examining my health. & 2.471 & 1.891 & 0.847 \\
5. I'm alert to changes in my health. & 2.331 & 1.975 & 0.724 \\
6. I'm usually aware of my health. & 2.495 & 1.309 & 0.822 \\
7. I'm aware of the state of my health as I go through the day. & 2.951 & 0.994 & 0.814 \\
8. I notice how I feel physically as I go through the day. & 3.190 & 1.280 & 0.832 \\
9. I'm very involved with my health. &
\end{tabular}

Notes: * Based on Gould (1988).

${ }^{* *}$ Overall Alpha $=0.849$.

Source: author

Cronbach's alpha is used to investigate the reliability (accuracy and reliability of a research tool) within the internal consistency of the selected scale. As we can see, the total value of Cronbach's alpha value is 0.849 , which can be interpreted as high value (Tavakol \& Dennick, 2011). From a practical point of view, it should also be stated that if the Cronbach's alpha value for the individual statements is higher than a total value, it is advisable to exclude this statement in future researches, as this will increase the overall accuracy and reliability of the research tool - in our case HCS_2. As we can see, it is not appropriate to rule out any of the statements. The standard deviation of the mean represents the dispersion of the calculated arithmetic mean across the different samples selected from one main population. The standard deviation shows to what extent the individual measured values are around the mean value. The smaller the standard deviation $\underline{i s}$, the closer the measured values are around the mean value. If the variance is smaller, it can be understood that the statement was rated similarly by all respondents. In our case, we can see more significant deviations in the following statements: 5 and 6.

Based on aims, we propose the following hypotheses and research questions:

RQ1: What is the level of health consciousness under normal conditions (pandemic-free period)?

$\mathrm{H} 1$ : There is a relationship between selected demographic indicators and the level of health consciousness of Slovaks under normal conditions.

RQ2: What is the level of health consciousness in a pandemic?

$\mathrm{H} 2$ : There is a relationship between selected demographic indicators and the level of health consciousness of Slovaks in an emerging pandemic. 
RQ3: What are the differences in the health consciousness of Slovaks under normal and extraordinary conditions of a pandemic?

H3: Regions with a higher level of health consciousness reach a lower number of infected with the coronavirus.

\section{Results and Discussion}

The aim is fourfold: 1 . to measure the level of health consciousness in normal conditions 2 . to measure the level of health consciousness during a pandemic 3 . to examine the differences between these levels and 4. to determine the true meaning of health consciousness in a pandemic. Based on the aims, we have developed hypotheses and research questions, the verification and answers of which we focus on in the next chapter of the article. Since the measurement was performed in two phases, we will call the first phase (before the pandemic) HCS_1 and the second phase (during the pandemic) HCS_2.

$R Q 1:$ What is the level of health consciousness under normal conditions?

The average measured value of HCS in Slovakia was 10.45 points (st. dev. 3.400), which is below the average in scale (scale average - 18; $<0,36>$ scale). The average calculation error is 0.173 points. The lowest measured rate of HCS_1 has reached 0 points, which is the smallest possible measurable value. The modus represents a value of 13 points and a median of 12. The total value measured value HCS_1 as considerably lower than average.

$\mathrm{H} 1$ : There is a relationship between selected demographic indicators and the level of health consciousness of Slovaks under normal conditions.

The average measured values and their standard deviations in individual segments were recorded in Table 4 for clarity.

Table 4 I HCS_1 results for individual segments

\begin{tabular}{c|l|c|c}
\hline Factor & Mean HCS_1 & St. dev. \\
\hline \multirow{2}{*}{ Gender } & Men & 10.26 & 3.464 \\
& Women & 10.63 & 3.337 \\
\hline \multirow{3}{*}{ Age } & 15-39 years old & 8.52 & 2.254 \\
& 40-64 years old & 11.45 & 3.056 \\
& Older than 65 years & 12.46 & 4.081 \\
\hline \multirow{5}{*}{ Region } & Banskobystrický & 13.96 & 1.849 \\
& Bratislavský & 4.51 & 2.322 \\
& Košický & 12.98 & 1.543 \\
& Nitrianský & 10.56 & 1.335 \\
& Prešovský & 12.60 & 1.350 \\
& Trenčianský & 9.67 & 1.223 \\
& Trnavský & 11.85 & 0.362 \\
& Žilinský & 6.57 & 0.764 \\
\hline
\end{tabular}

Source: author

As can be seen in Table 4, significant differences can be seen with age and residence factors, but gender is not indiscreet as a significant factor affecting HCS. However, these results are indicative only. 
To verify the Hypothesis (H1), we used a one-way ANOVA test. Hypothesis $1(\mathrm{H} 1)$ consists of three variables. Therefore we decided to divide $\mathrm{H} 1$ into three parts: $\mathrm{H} 1 \mathrm{a}$ is examining the age factor, $\mathrm{H} 1 \mathrm{~b}$ is examining the sex factor, and $\mathrm{H} 1 \mathrm{c}$ is examining the fact factor of residence. The results of the ANOVA test were recorded by Table 5.

Table 5 I Hypotheses Evaluation Results (ANOVA)

\begin{tabular}{c|c|c|c|c|c|c}
\hline & F - value & F - crit. & F-F crit. & $\alpha$ & p-value & $\alpha$ - p-value \\
\hline H1a & 57.002 & 3.019 & F $>$ F crit. & 0.05 & 0.000 & $\alpha>p$-value \\
H1b & 1.153 & 3.866 & F < F crit. & 0.05 & 0.283 & $\alpha<p$-value \\
H1c & 241.948 & 2.034 & F > F crit. & 0.05 & 0.000 & $\alpha>p$-value \\
\hline
\end{tabular}

Source: author

Based on the above results from Table 5 ( $F>F_{\text {crit }}$ ), hypotheses $\mathrm{H} 1 \mathrm{a}$ and $\mathrm{H} 1 \mathrm{C}$ can be confirmed. Hypotheses confirmation are supported by the fact that $\alpha>\mathrm{P}$-value. It can therefore be rejected that this is merely noise or a random factor and confirms the statistically significant impact of the age and residence as a factor on consumer health consciousness. We reject the hypothesis $\mathrm{H} 1 \mathrm{~b}$ based on the results.

The results of the first phase of the research (before the pandemic) can be summarized as follows:

- Under normal conditions, Slovak consumers achieve a significantly below-average level of health consciousness.

- Older consumers are more health-conscious than younger ones.

- There are significant differences between health consciousness from the perspective of the regions of Slovakia.

- Women and men achieve roughly the same results of health consciousness, and therefore gender is not a significant factor affecting the level of health consciousness.

RQ2: What is the level of health consciousness in a pandemic?

The mean measured value of HCS in Slovakia was 25.92 points (st. dev. 4.386), which is over the average in scale (scale average - 18; $<0,36\rangle$ scale). The average calculation error is 0.22 points. The lowest measured rate of HCS_2 has reached 11 points. The modus represents a value of 26 points and a median of 26 . The total value measured value HCS_2 as considerably higher than average.

$\mathrm{H} 2$ : There is a relationship between selected demographic indicators and the level of health consciousness of Slovaks in an emerging pandemic.

The average measured values and their standard deviations in individual segments were recorded in Table 4 for clarity. 
Table 6 I HCS_2 results for individual segments

\begin{tabular}{c|l|c|c}
\hline Factors & Mean HCS_2 & St. dev. \\
\hline \multirow{2}{*}{ Gender } & Men & 23.30 & 2.164 \\
& Women & 28.41 & 4.514 \\
\hline \multirow{3}{*}{ Age } & 15-39 years old & 22.22 & 2.546 \\
& 40-64 years old & 27.93 & 1.441 \\
& Older than 65 years & 29.54 & 5.843 \\
\hline \multirow{5}{*}{ Region } & Banskobystrický & 31.72 & 3.298 \\
& Bratislavský & 18.91 & 2.968 \\
& Košický & 29.29 & 3.155 \\
& Nitrianský & 25.54 & 2.721 \\
& Prešovský & 27.48 & 2.242 \\
& Trenčianský & 25.67 & 1.074 \\
& Trnavský & 25.30 & 0.648 \\
& Žilinský & 22.31 & 0.983 \\
\hline
\end{tabular}

Source: author

As can be seen in Table 6 , significant differences can be seen with age, gender and residence factors. However, these results are only indicative. To verify the Hypothesis $(\mathrm{H} 2)$, we used a one-way ANOVA test. Hypothesis $2(\mathrm{H} 2)$ consists of three variables. Therefore we decided to divide $\mathrm{H} 2$ into three parts: $\mathrm{H} 2 \mathrm{a}$ examining the age factor, $\mathrm{H} 2 \mathrm{~b}$ is examining the gender factor, and $\mathrm{H} 2 \mathrm{C}$ is examining the fact factor of residence. The results of the ANOVA test were recorded in Table 5.

Table 7 I Hypothesis Evaluation Results (ANOVA)

\begin{tabular}{c|c|c|c|c|c|c}
\hline & F - value & F - crit. & F-F crit. & $\alpha$ & p-value & $\alpha$ - p-value \\
\hline H1a & 190.613 & 3.019 & F > F crit. & 0.05 & 0.000 & $\alpha>p$-value \\
H1b & 196.448 & 3.866 & F > F crit. & 0.05 & 0.000 & $\alpha>p$-value \\
H1c & 112.329 & 1.963 & F > F crit. & 0.05 & 0.000 & $\alpha>p$-value \\
\hline
\end{tabular}

Source: author

Based on the above results from Table 7 ( $\left.F>F_{\text {crit }}\right)$, hypotheses $\mathrm{H} 2 \mathrm{a}, \mathrm{H} 2 \mathrm{~b}$ and $\mathrm{H} 2 \mathrm{c}$ can be confirmed. Hypotheses confirmation are supported by the fact that $\alpha>p$-value. It can therefore be rejected that this is merely noise or a random factor and confirms the statistically significant impact of the age, gender and residence on consumer health consciousness.

The results of the second phase of the research (during the pandemic) can be summarized as follows:

- At the time of the pandemic, Slovaks reached an above-average level of health consciousness.

- Women are more health-conscious than men.

- Older consumers are more health-conscious than younger ones.

- There are significant differences between health consciousnesses from the perspective of the regions of Slovakia.

RQ3: What are the differences in the health consciousness of Slovaks under normal and extraordinary conditions of a pandemic? 
In general, the pandemic's health consciousness mean increased to $248 \%$ of the prepandemic value. We scored the scores for the individual statements of the scale in both phases in Figure 1. The highest increase was measured in statement 4 - I'm constantly examining my health (an increase of about $265 \%$ ) and the lowest increase was in statement 7 - I'm aware of the state of my health as I go through the day (an increase of about $71 \%$ ). As can be seen, there are significant differences in assessment before and during the pandemic.

\section{Figure 1 I HCS_1 and HCS_2}
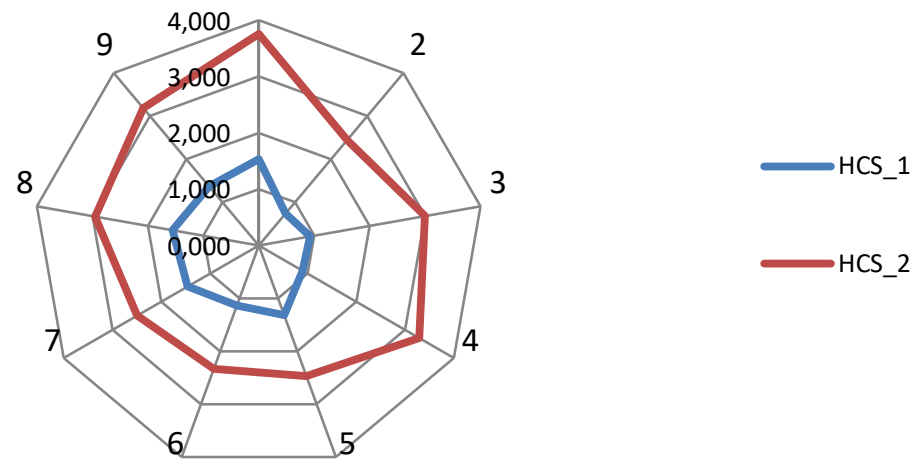

Source: author

The measured values from both phases in terms of individual factors (segments) were recorded in Figure 2.

\section{Figure 2 I HCS_1 and HCS_2 based on segments}

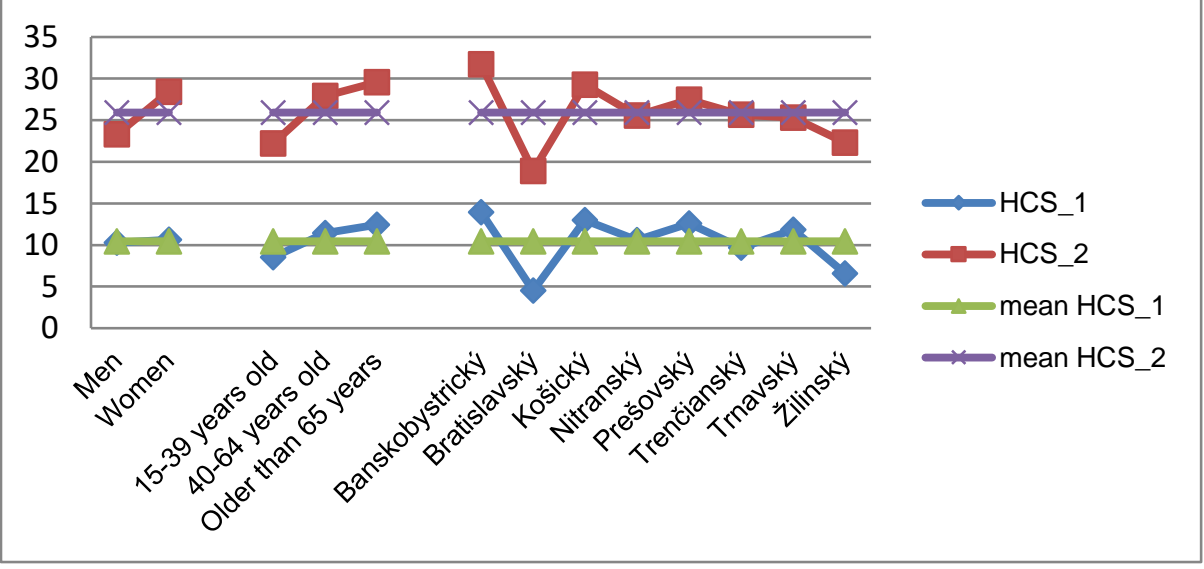

Source: author

As shown in Figure 2, the measured values at the time of the pandemic are significantly higher. It is interesting to note that the shape of the curves is almost identical before and 
during the pandemic, which only confirms that the factors examined are significant and that nearly every segment has experienced roughly the same increase. The trend line in both cases (HCS_1, HCS_2) corresponds to the average measured value of the scale.

H3: Regions with a higher level of health consciousness reach a lower number of infected with the coronavirus.

The number of infected and average HCS_2 values in terms of regions was recorded in Table 8.

Table 8 I Region - HCS_2 mean and the numbers of infected with COVID_19

\begin{tabular}{c|l|c|c}
\hline \multicolumn{2}{c|}{ Factor } & HCS_2 mean & Number of infected with coronavirus * \\
\hline \multirow{6}{*}{ Region } & Banskobystrický & 31.72 & 52 \\
& Bratislavský & 18.91 & 196 \\
& Košický & 29.29 & 90 \\
& Nitrianský & 25.54 & 44 \\
& Prešovský & 27.48 & 88 \\
& Trenčianský & 25.67 & 86 \\
& Trnavský & 25.3 & 61 \\
& Žilinský & 22.31 & 84 \\
\hline
\end{tabular}

Legend: * data from 09. April 2020, based on PHASR (2020).

Source: author

The hypothesis was verified based on one-way ANOVA test. Based on the above results $\left(F>F_{\text {crit }}\right)$, hypotheses $\mathrm{H} 3$ can be confirmed. Hypotheses confirmation are supported by the fact that $\alpha(0.05)>P$-value (0.002). It can therefore be rejected that this is merely noise or a random factor and confirms the statistically significant relationship between health consciousness and numbers of infected with the coronavirus.

We used regression analysis to determine the direction and intensity of this relationship. Multiple R-value (correlation coefficient) is 0.695 . This value is close to 1 , so the dependence is strong. The $R$ Square value is the value of the coefficient of determination; the value is 0.482 . This value after interpolation 100 indicates that the selected regression line explains revenue variability to approximately $48.2 \%$; the other part represents an unexplained variability; the impact of random factors and other unspecified impacts. The standard deviation (3.08) is acceptable due to the depth of the tool used. The regression analysis has a negative character.

One-way ANOVA test and regression analysis confirm that regions with higher levels of health consciousness have a lower number of infected.

\section{Conclusion}

The aim is fourfold: 1 . to measure the level of health consciousness in normal conditions 2 . to measure the level of health consciousness during a pandemic 3 . to examine the differences between these levels and 4. to determine the true meaning of health consciousness in a pandemic. 
The article is based on two surveys - the first phase took place before the pandemic and the second phase during the pandemic. In both phases, 384 respondents were selected based on the quota method.

The results show low health consciousness of Slovaks under normal conditions. We have shown that under these conditions, two demographic factors - age and residence - have a significant impact.

Under pandemic conditions, health consciousness is rapidly increasing, which is logical given the emergency. During a pandemic, health consciousness is influenced by age, gender and residence. In general, older respondents achieved a higher level of health consciousness. Gender as a significant factor was only shown during the pandemic. It can be unambiguously argued that women reach a higher level of health consciousness during a pandemic. Interestingly, there are more infected men in Slovakia, although, in terms of demography, there are more women in Slovakia. This disparity can be explained by the high health consciousness of women.

Residence (region) is an important factor in health consciousness. Different rates have been found in different regions. We consider it essential to prove the relationship between the level of health consciousness and the number of people infected in the given regions. It can be stated that regions with a higher level of health consciousness reach a lower number of infected people (negative relationship).

Based on the results of the study, it can be stated that the impact of the pandemic and infected consumers can be largely minimized by increasing consumer health consciousness, which ultimately leads to stabilization of the economic situation.

All three market players (households, businesses, state) can use the results of our study to achieve better preventive measures.

For households, health consciousness is an important factor in preventing pandemics. There is a need to increase overall vigilance in the context of health status, self-awareness, involvement in health improvement and control.

Businesses should increase worker safety and create conditions for increasing employee health. Logically, investment in the health of employees will be reflected in a reduction in the number of incapacities for work, which leads to increased productivity not only during a pandemic. We consider it essential to develop procedures to eliminate the risks of moving not only the coronavirus but also others. Adherence to hygiene principles seems to be one of the best preventive measures. Service companies should adhere to the high hygiene standard of their employees. Create policies and contingency plans for critical (pessimistic) market scenarios. The geographical diversity of suppliers can be useful in an emergency, especially concerning the procurement of critical components for production. It is important for companies to regularly update strategies aimed at organizational growth and changes in the business environment. For the regions, the worst results of health awareness were obtained by the Bratislava region, where a large number of large companies are concentrated, which represents a significant risk.

In the conditions of Slovakia, the state creates various measures and interventions not only in the economic sphere. The effectiveness and efficiency of these tools will only be demonstrated in the future. 
The results can be used in medicine, in sociological sciences and marketing. It is necessary to support segments with a high level of health consciousness, while at the same time increasing the level of consciousness of segments with low health consciousness.

In the future, research in other countries would also be appropriate. At the same time, we consider it appropriate to examine the level of health consciousness after the end of the pandemic.

\section{Acknowledgement}

The research was conducted within a Research Project VEGA 1/0339/18 "Health conscious consumer behaviour: determinants, perspectives and intervention possibilities ".

\section{References}

Adler, S.E. (2020). Why Coronaviruses Hit Older Adults Hardest. Retrieved April 11, 2020, from <https://www.aarp.org/health/conditions-treatments/info-2020/coronavirus-severe-

seniors.html>.

Baláž, V. (2020). Ekonomické súvislosti pandémie. Učená spoločnost' Slovenska. Retrieved June 16, 2020, from <https://www.learned.sk/ekonomicke-suvislosti-pandemie/>.

Centre for Disease Control and Prevention (2020a). Interim infection prevention and control recommendations for patients with suspected or confirmed coronavirus disease 2019 (COVID19) in healthcare settings. Centre for Disease Control and Prevention. Retrieved April 07, 2020, from <https://www.cdc.gov/coronavirus/2019-ncov/infection-control/control recommendations.html>.

Centre for Disease Control and Prevention (2020b). Interim guidelines for collecting, handling, and testing clinical specimens from persons for coronavirus disease 2019 (COVID-19). Centre for Disease Control and Prevention. Retrieved April 07, 2020, from <https://www.cdc.gov/coronavirus/2019-ncov/lab/guidelinesclinical-specimens.html.>

Dun \& Bradstreet (2020). Business Impact of the Coronavirus: Business and Supply Chain Analysis Due to the Coronavirus Outbreak. Special briefing. CREATIVEUX-1808 02/20.

ECDPC (2020). COVID-19 pandemic. Retrieved April 10, 2020, from $<$ https://www.ecdc.europa.eu/en/covid-19-pandemic>.

Gostic, K., Gomez, A. C., Mummah, R. O., Kucharski, A. J. \& Lloyd-Smith, J. O. (2020). Estimated effectiveness of symptom and risk screening to prevent the spread of COVID-19. Elife. 9. pii: e55570.

Gould, S. J. (1988). Consumer Attitudes Toward Health and Health Care: A Differential Perspective. Journal of Consumer Affairs, 22, 96-118.

Gould, S. J. (1990). Health consciousness and health behavior: The application of a new health consciousness scale. American Journal of Preventive Medicine, 6 (4), 228-237.

Chen, N., Zhou, M., Dong, X., QU, J., Gong, F., Han, Y., Qiu, Y., Wang, J., Liu, Y., Wei, Y., Xia, J. A., Yu, T., Zhang, X., \& Zhang, L. (2020). Epidemiological and clinical characteristics of 99 cases of 2019 novel coronavirus pneumonia in Wuhan, China: a descriptive study. Lancet, 395(10223), 507-513.

Jayanti, R. K. \& Burns, A. C. (1998). The antecedents of preventive health care behavior: an empirical study. Journal of the Academy of Marketing Science, 26 (1), 6-15. 
Kemp, E. \& Bui, M. (2011). Healthy brands: Establishing brand credibility, commitment and connection among consumers. Journal of Consumer Marketing, 28 (6), 429-437.

Lockie, S., Lyons, K., Lawrence, G. \& Mummery, K. (2002). Eating 'green': motivations behind organic food consumption in Australia. Sociologia Ruralis, 42 (1), 23-40.

Michaelidou, N. \& Hassan, L. M. (2008). The role of health consciousness, food safety concern and ethical identity on attitudes and intentions towards organic food. International Journal of Consumer Studies, 32 (2), 163-170.

Nozdrovická A. (2020). Svetová vírusová kríza a jej vplyv na svetovú ekonomiku. Slovenská Akadémia Vied. Retrieved June 16, 2020, from $<$ https://www.sav.sk/index.php?doc=servicesnews\&source_no=20\&news_no=8862>.

PHASR (2020). COVID-19: Celkovo 20.670 negatívnych vzoriek, potvrdených prípadov ochorenia 701. Retrieved April 01, 2020, from $<$ http://www.uvzsr.sk/index.php?option=com_content\&view=article\&id=4189:covid-19-celkovo20670-negativnych-vzoriek-potvrdenych-pripadov-ochorenia-701\&catid=250:koronavirus-2019ncov\&Itemid=153>.

PHASR. (2020). Public Health Authority of the Slovak Republic : Úrad verejného zdravotníctva Slovenskej republiky. Retrieved April 09, 2020, from <http://www.uvzsr.sk/index.php?option=com_content\&view=article\&id=4189:covid-19-celkovo20670-negativnych-vzoriek-potvrdenych-pripadov-ochorenia-701\&catid=250:koronavirus-2019ncov\&ltemid $=153 \% 3 E>$.

Sørensen K., et al. (2012). Consortium Health Literacy Project European. Health literacy and public health: A systematic review and integration of definitions and models. BMC Public Health $2012,12,80-93$

SOSR. (2020). Statistical Office of the Slovak Republic. Štatistický úrad Slovenskej republiky. Retrieved April 09, 2020, from <http://datacube.statistics.sk/\#!/view/sk/SODB/hc1okr/Obyvate\%C4\%BEstvo\%20pod\%C4\%BE a\%20miesta\%20s\%C4\%8D\%C3\%ADtania,\%20pohl.,\%20postav.\%20v\%20dom\%C3\%A1c.,\%2 Orodinn.\%20stavu,\%20ekonom.aktivity,\%20miesta\%20narod.,\%20\%C5\%A1t\%C3\%A1t.\%20pr \%C3\%ADslu\%C5\%A1.\%20a\%20veku\%20-\%20HC1>.

Stokes, J., Noren, J., \& Shindell, S. (1982). Definition of terms and concepts applicable to clinical preventive medicine. Journal of Community Health, 8 (1), 33-41.

Tavakol, M. \& Dennick, R. (2011). Making sense of Cronbach's alpha. International Journal of Medical Education, 2 (1), 53-55.

WHO (2020). Constitution. Retrieved April 09, 2020, from <https://www.who.int/about/who-weare/constitution>.

WARC. (2020). Indonesia gets health-conscious amid COVID-19 pandemic. Retrieved April 09, 2020, from <https://www.warc.com/newsandopinion/news/indonesia-gets-health-conscious-amidcovid-19-pandemic/43461>.

Wu, Z. \& McGoogan, J. M. (2020). Characteristics of and important lessons from the coronavirus disease 2019 (COVID-19) outbreak in China: summary of a report of 72314 cases from the Chinese Centre for Disease Control and Prevention. JAMA.

The research paper passed the review process. | Received: May 27, 2020; Revised: June 17, 2020; Accepted: June 29, 2020; Published: September 30, 2020. 